Article

\title{
Can Indigenous Knowledge Contribute to the Sustainability Management of the Aspiring Rio Coco Geopark, Nicaragua?
}

\author{
Martina Pásková (iD) \\ Faculty of Informatics and Management of University of Hradec Králové, Rokitanského 62, \\ 50003 Hradec Králové, Czech Republic; martina.paskova@uhk.cz; Tel.: +420-602-643-054
}

Received: 3 May 2018; Accepted: 10 July 2018; Published: 27 July 2018

check for updates

\begin{abstract}
Indigenous knowledge in the UNESCO Global Geoparks represents an important emerging research topic. This study investigates aspects of the indigenous environmental knowledge in the southern part of the aspiring Rio Coco Geopark (Nicaragua) and its potential to enhance the sustainability management of geotourism and other geopark activities. The ethnographic method has been implemented in the form of semi-structured interviewing of the representatives of local households and through the application of participant observation. Related field research methods included documentation of the life history of Elders, focal group discussions, GPS mapping, photo-documentation, and problem tree analysis. The results indicate that the best-conserved indigenous environmental knowledge relates to the use of land, rocks, and plants, while the expression and transmission of the spiritual dimension of this traditional knowledge are declining. The key implications of the observed indigenous knowledge for the geopark decision-makers include the identified potential for its sustainability management, geotourism and geo-interpretation opportunities, as well as the conditions for the implementation of this potential.
\end{abstract}

Keywords: indigenous knowledge; geopark; geotourism; Nicaragua; sustainability management

\section{Introduction}

One of the greatest challenges for humankind is undoubtedly the sustainable use of natural resources to ensure continued human progress and development. The science sector of highly developed societies offers immense potential for solution of this difficult task, but crucial global problems, like climate change and biodiversity loss, as well as their local effects, still remain unsolved and others are emerging. With the growing seriousness of this situation, modern society is searching for more holistic and integrated approaches to environmental management.

Sustainability management has been developed since the 1980s to manage the internal processes within an organisation to reduce its environmental impact. Gradual development of formal and certified environmental management systems, followed by the Total Quality Management concept, led to an informal approach to Total Environmental Quality Management [1]. Current management theory, however, does not take sufficient account of the dynamically changing external environment of the organization, and it lacks a consistent link between management and its environmental and socio-cultural environment [2]. Sustainability management theory [2] is based on a consistent system and process approach including the interconnection of organizations, society, individuals and the environment. This approach is complemented by a theory of interest groups, based on a shared sustainability value among all interest groups [3]. The conditions for the development of this kind of cooperation are education, value creation and regulation [3] (pp. 338-340). This enhanced sustainability management theory can also be applied in regional sustainability management and 
in tourism sustainability management, including tourism destinations (e.g., [1,4-6]) and geoparks (e.g., [7-12]).

In developing the sustainability management approach, which is reflected in higher-level collective memory and geographical context, scientists are rediscovering and increasingly appreciating the nature-related ancestral knowledge that is gathered and verified by generations of indigenous peoples (e.g., [8-11,13-18]). In spite of the importance for the involvement of indigenous knowledge in land management, the potential is not researched adequately. The question arises as to whether there exists a causal correlation between the indigenous use intensity and the quality of land sustainability management.

Local and indigenous people not only have the knowledge regarding individual species and habitats, they have also encoded substantial knowledge in their spiritual life in the form of rituals, beliefs, legends and taboo concepts (e.g., [19-26]). Some authors have even provided the explanation and categorization of "ecological functions of social taboos" (e.g., [27,28], [29] (p. 32)). Regarding land management, the concept of "sacred groves" practised in many regions and localities of the world, seems to have a very important role in land use sustainability, as described e.g., for Kyrgyzstan sacred sites [30]. In this respect, the indigenous knowledge includes the traditional perception and usage of carrying capacity verified over time, as described in detail in the Siberian taiga case study [31]. Specifically, regarding e.g., the Siberian pine, the multiuse resource management respecting the carrying capacity of the forest to recover its ecosystems has been observed [31] (p. 1300): "Stone pine, also called cedar or kedr (Pinus sibiricus), is considered a sacred tree by Altaians, and is a good example of the use of plants for traditional purposes. Each part of the tree can be used. The resin was used to make a chewing gum that helped to clean teeth. Seedlings were boiled and the infusion was used to rinse out a person's eyes. Cedar nuts had many traditional uses; for example, chewing a handful of nuts was thought to heal throat ailments, and nuts were used to produce cedar "milk" and butter. Cedars were protected, so that only dead trees that were already dried out were used for firewood. Living trees were treated as living forest capital and were not cut unless absolutely necessary, and only when they could be taken without damaging wildlife or other aspects of the taiga ecosystem."

More scientific attention should be devoted to the role in indigenous knowledge in sustainability management. The application of indigenous knowledge in land management (e.g., [29,32]) seems to be still underestimated. Regarding Earth heritage related indigenous knowledge, there are few studies dedicated to this theme (e.g., [20,21,24-26]).

The important, nearly paradigmatic, modality of research that is focused on indigenous knowledge is represented by the application of the participatory approach [33], which has been implemented in research located in biologically (e.g., [34,35]), or geologically significant areas (e.g., [8-11,36]). Taking into account the sensitivity of this research subject, the application of the participatory method is necessary. There is not only the ethical question of the intellectual property rights (e.g., [37,38]), but also the geopolitical question of indigenous identity. The participatory research process can support or even stimulate the reactivation of indigenous identity (e.g., [9,13,34]).

In this context, the search for the optimal synergic combination of scientific and indigenous knowledge systems (Figure 1) represents an important challenge for sustainability management (e.g., [13,14,18,32]), especially in protected areas (e.g., [39-42]) and other areas with a high capacity for providing ecosystem services (e.g., [4,8,27,28,34,35]). 


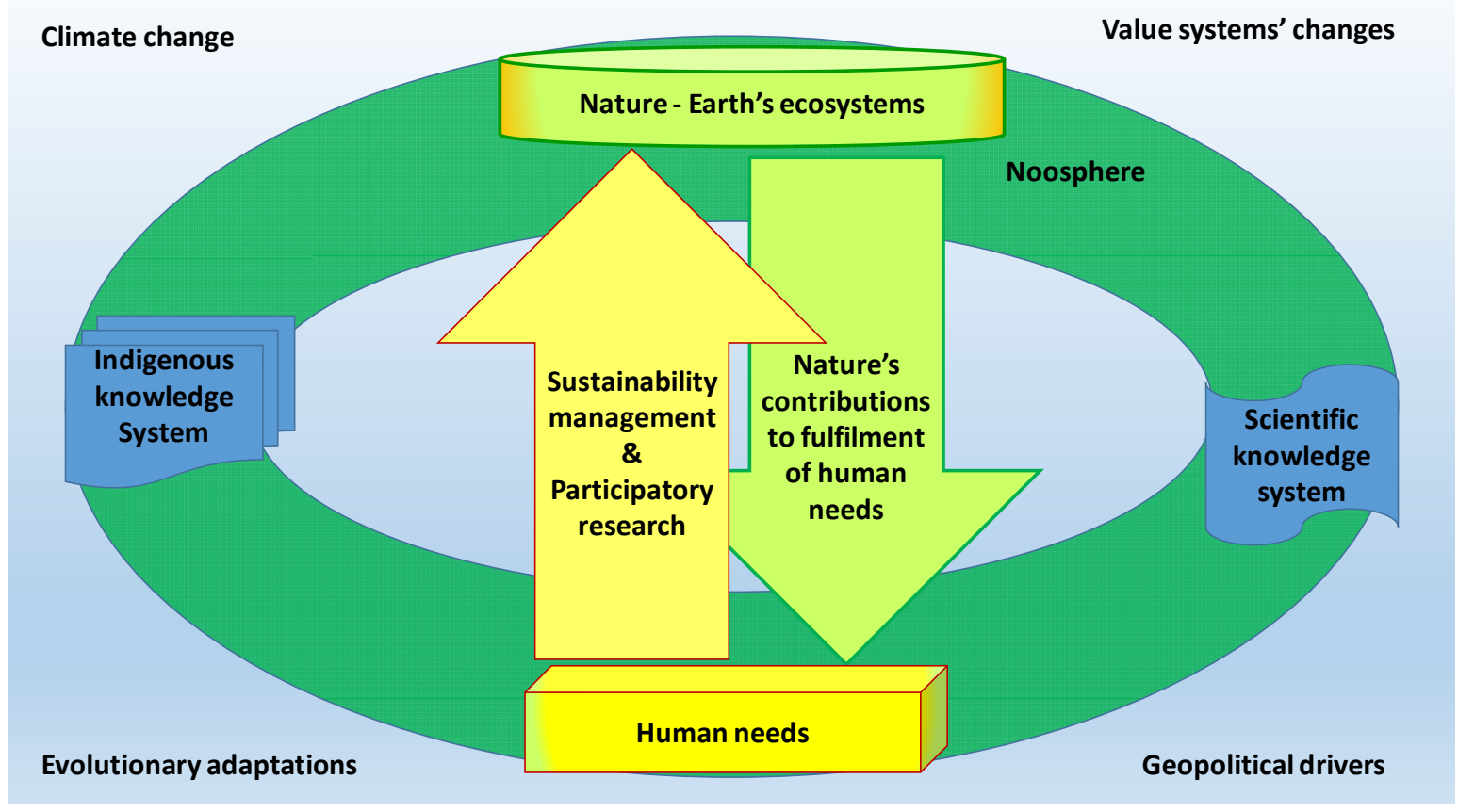

Figure 1. Traditional and scientific knowledge concerning sustainability management as a part of the Noosphere.

The UNESCO Global Geoparks focus their mission on research-based conservation and participative development of the geological heritage, as well as its holistic interpretation interlinking the local geological characteristics to the local intangible heritage and other aspects of the local life $[7,12,43]$. Numerous geoparks include areas that are occupied by indigenous communities [11], which is reflected by fact that one of the "Top 10 Focus Areas of the UNESCO Global Geoparks" is "Local and Indigenous Knowledge" [43]. These communities are still strongly connected to nature, they perceive it as a sacred living being, "Mother Earth", and they develop, maintain, and transmit empirically based (inductive) knowledge about "her" and all the natural resources they use for their subsistence (e.g., [8-11,13-15,18,35]). This kind of knowledge system differs substantially from the schematized (deductive) knowledge system used by geopark geoscientists (e.g., [7,8]). In this way, the UNESCO Global geoparks represent natural "laboratories", which can be used for studies of the power of indigenous knowledge for the sustainability management of land use and other natural resources. The Earth is at the heart of the geoparks mission, as well as of the indigenous knowledge corpus. Aspiring Rio Coco Geopark (Nicaragua) [44] has been serving as such a laboratory more than six years [8-11] and it offers good opportunities for further research in this field.

Pacific, Central, and Northern Nicaragua is home to 22 indigenous communities occupying $32 \%$ of its territory [42]. In 2016, the International Union for Conservation of Nature (IUCN) mapped the potential benefit of cooperation among local conservationists, governments, and indigenous peoples [42]. The study concluded that recognizing and respecting indigenous peoples' rights to observe their own traditional subsistence practices and lifestyle could assist in preventing the undesirable effects of global environmental problems, like climate change, deforestation, and biodiversity loss [42].

Previous studies have analysed the importance of indigenous knowledge in the sustainable development of geoparks and geotourism [8-11], but the purpose of the present study was to identify in detail the indigenous environmental knowledge and to indicate its potential for sustainability management of geotourism and other geopark activities. To achieve this objective, an ethnographic investigation was undertaken in the aspiring Rio Coco Geopark. The findings correspond with previous results [8-11] and they indicate that the best-conserved indigenous environmental knowledge 
there relates to the use of land, rocks, and plants, while the expression and transmission of the spiritual dimension of this traditional knowledge are declining. Based on these results, the potential for the sustainability management of geotourism and other activities of this aspiring geopark was identified, as well as the conditions for implementation of this potential.

\section{Research Process}

\subsection{Research Design}

This study is a part of ongoing research [8-11] applying interdisciplinary, holistic, post-cultural, place-based, and people-centred approaches [8]. Its theoretical background is premised on following disciplines and fields of human science: ecological anthropology [32,37], cognitive anthropology [37,45], adaptive management [32,41], and possibilism in the frame of human geography, in particular, the concept of "genre de vie" [46] focusing on the human imprint in the landscape [47].

As a framework for researching indigenous environmental knowledge and its potential for sustainability management, the basic research question was formulated in the following way: "What relationship exists between indigenous knowledge and sustainability of land use as well as use of the natural resources of the aspiring Rio Coco Geopark?" In summer 2017, the research was carried out in the form of a case study aiming to identify the local indigenous environmental knowledge and to indicate its potential for enhancement of the sustainability management of geotourism and other geopark activities. It was framed by the specific (itemized and localized) research question that was derived from the general research question above: "Can the knowledge of indigenous people living in El Apante community contribute to the sustainability management of the aspiring Rio Coco Geopark, especially to its geotourism sustainability management?"

\subsection{Study Area}

The Rio Coco Geopark project represents the first territory aspiring to become a UNESCO Global Geopark in Nicaragua. It is located in the mountainous region of north-western Nicaragua, on the border with Honduras. Its area covers $954 \mathrm{~km}^{2}$ [44] and it consists of the substantial part of the Madriz Department. Its 74,224 inhabitants live in five municipalities [44], three of them recognized as indigenous communities: San José de Cusmapa, San Lucas, and Totogalpa. The Rio Coco Geopark headquarters is located in the town of Somoto, which is the capital of the Madriz Department.

The climate of the aspiring geopark is dry subtropical, being located in the dry corridor of the region, which produce its high vulnerability to climate change and heavy rains [44]. The geoheritage of the aspiring geopark "belongs to the Caribbean Plate, comprising several structural levels from Palaeozoic greenschist-facies metamorphic terrane intruded with Cretaceous granite pluton to Upper Tertiary volcanic sequences" [44].

The indigenous inhabitants of the Rio Coco territory are defined by the state as Chorotegas, who were descendants of Maya ethnics migrating around the eighth century to the Northern and Pacific region of Nicaragua from the area of present Chiapas or Cholula (Mexico) [8,42,48]. They had received their official land titles ("Titulos Reales") already in 1662 [48] (p. 71). However, according to some recent anthropological findings [49] the indigenous peoples of Central and Northern Nicaragua had not been Chorotegas, but Matagalpas. As explained by Navarro-Genie [49], "they call themselves Chorotegas because of the lack of anthropological knowledge regarding their roots". Local indigenous people are living in small dispersed communities that are characterized by a diet based on the "basic grains" (corn, beans, and sorghum) and by the use of traditional ceramics and textile handcrafts. They speak vernacular, which is kind of mixture of Latin American Spanish with Nahuat (one informant has termed it as "Pupuluca" dialect). Nahuat, as a dialect of the Nahuatl language, was the Nicaraguan "lingua franca" between the 16th and 19th centuries [50].

The community El Apante (Figure 2) was selected as a research area for this case study to geographically balanced distribution of ongoing research localities and for its relative isolation from 
the urbanized area. This community is located in the southern part of the aspiring geopark, in the administrative area of the Municipality of San José de Cusmapa. This municipality is situated in the mountainous region, inside of Natural Reserve Serranía Tepesomoto y Pataste, which is home to species related to the local ecosystems that are formed by the altitudinal gradient [48]. The local vegetation consists predominantly of oak forests and mixed pine (Pinus oocarpa) and oak forests, but there are various epiphytes, mainly orchids and bromeliads [48]. The larger size animals are represented by puma called locally "leoncillo" (Puma concolor), deer called locally "venado cola blanca" (Odocoileus virginianus), and boar called locally "saíno" (Pecari tajacu), but there are many species of birds and Chiroptera [48] (p. 18). The natural axis of the area is created by the Tapacali River Basin, which rises in the Municipality of San José de Cusmapa, then it flows into the Rio Coco river, and finally runs into the Caribbean. This part of the aspiring geopark is relatively humid, which corresponds with informants' interpretation of the word "Apante", which means "abundance of water". The average annual precipitation ranges between $1200 \mathrm{~mm}$ and $1600 \mathrm{~mm}$ [48] (p. 35).

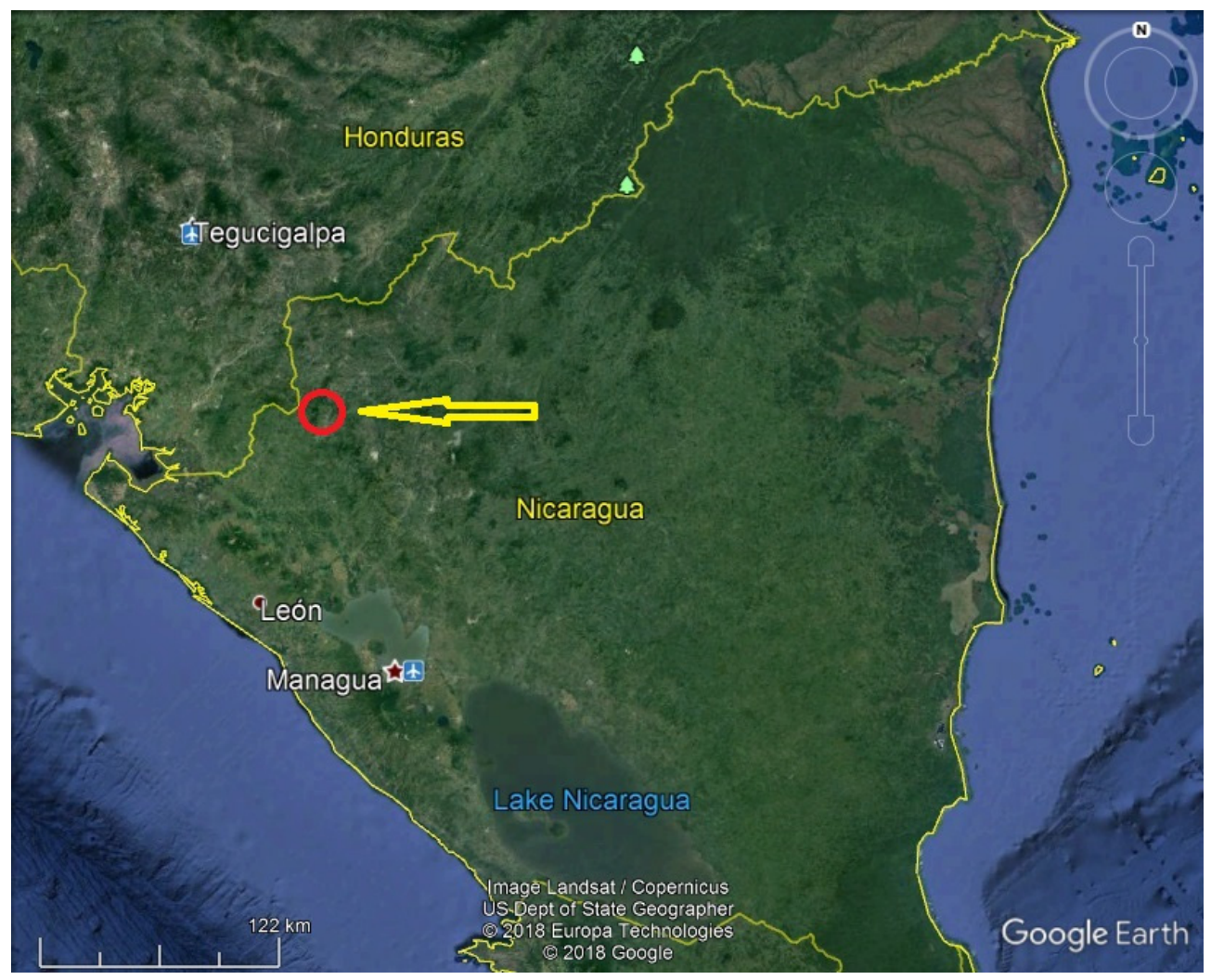

Figure 2. Location of the research area in the map of Nicaragua (red circle). Source: Google Earth.

The Tepesomoto-Pataste Mountains represent a continuous chain of summits that are aligned along an ancient fault of the Tertiary period, where a series of coalescing base volcanoes arose [51] (p. 4). The average altitude is $1280 \mathrm{~m}$ a.s.l.; Buena Vista (1665 $\mathrm{m}$ a.s.1.), El Arenal (1625 $\mathrm{m}$ a.s.1.), Apante (1588 $\mathrm{m}$ a.s.1.), Orocuina (1527 $\mathrm{m}$ a.s.1.), and Imire (1304 $\mathrm{m}$ a.s.1.) are among the highest summits of the region, while its lowest parts reach just $700 \mathrm{~m}$ a.s.1. [48] (p. 53). The volcanic character of the mountains is evidenced by the incidence of numerous basaltic and andesite rocks, as well as tuffs and dacite breccia that are characteristic of the formation called Upper Coyol, which corresponds to the culminating phases of Tertiary volcanism during the Pliocene [51] (p. 5).

According to information obtained from the focal group discussion, the El Apante population comprises approximately 500 indigenous persons who occupy 84 households. The local indigenous community is living in economically very poor conditions, and the majority of the population is categorized as extremely poor [52]. On the other hand, the environmental conditions are very rich, 
however fragile and somewhat risky (volcanic activity, tropical cyclones, landslides, etc.). This situation makes the local indigenous peoples strongly dependent on the natural processes and rhythms, which seems to contribute to their connection with, and respect for nature. According to participants of the focal group discussion and documents that are provided by Somoto Town Hall $[45,52])$, the majority of local people are self-employed in the cultivation of "basic grains" and other local cultivars, about $5 \%$ is occupied by extensive cattle farming and about $15 \%$ cultivates coffee. They practice predominantly auto-consumption, but some of them sell part of their production at the fair held once a week in San José de Cusmapa. They work also in forestry (cutting wood for construction and collecting "leña" for heating), implementing in some localities silvopastoral or agroforestry systems as an organic shade-grown coffee cultivation [48]. The local terrains are very difficult for cultivation; they mainly consist of steep slopes in altitude between $1000 \mathrm{~m}$ and $1600 \mathrm{~m}$ a.s.l. This kind of terrain makes the local soils prone to intensive erosion and landslides, especially during the wet season and tropical cyclones. There are still numerous destructive effects of the hurricane Mitch (1998) visible on the local slopes.

Possible future responsible development is supposed to be connected with the involvement of the community in the activities of the aspiring Rio Coco Geopark. Currently, the only geosite identified by aspiring geopark team for future geotourism in area of El Apante community is, except for geologically significant Natural Reserve Mangas Verdes, the rocky formation, called by local indigenous inhabitants "Piedra Orocuina" [44]. From the viewpoint of this volcanic hill, a cone shape or amphitheatric structure in the bottom of the valley is recognizable as well as the complex volcanic landscape.

Al Apante community, as a part of the indigenous municipality "Pueblo Indígena de San José de Cusmapa-Lugar Carrizal", is self-organized by the "Junta Directiva" called also "Junta Indigena". Its territory is determined by 37 slightly chiselled boulders, called "mojones" and consists of four sectors. Sector I represents a central area of the community, where a basic school building, "Indigenous House", very simple evangelic church and small playground are located as well as the household where the author was living for two weeks. Sector II, called "Ojo de agua", is situated to the south-west of the central area. Sector III, called "Mangas Verdes", is to the north-east and Sector IV, called "Marañon", is the most distant area, which is situated to the north-east of the central part of the community. $\mathrm{Al}$ Apante community lies about $4 \mathrm{~km}$ from San José de Cusmapa, but the access is extremely difficult because of hilly terrain with the steep slopes. The only road connecting the community with San José de Cusmapa is not paved, difficult to walk in many parts, and very dusty. There is no health centre in the community; the closest one is located in San José de Cusmapa, but some trained" brigadistas de salud" are present there and local indigenous peoples practice also a natural medicine. Concerning retail shopping, there are no shops in El Apante with the exception of three very small and simple in-house outlets. During the last decade, the government equipped nearly all of the households with solar panels, but many of them are already without electricity because of expired batteries.

\subsection{Methods}

This case study implemented a qualitative research strategy through a grounded theory approach [53,54]. Using the ethnographic method, participant observation was implemented in the form of sharing living with a household located in the Central sector of the El Apante community for two weeks and through semi-structured interviewing of the representatives of another seven households selected from all the four community sectors (Figure 3). The first four informants (representatives of the household) were selected purposively, in consultation with the key informant provided by the Town Hall of San José de Cusmapa as well as by the Junta Indígena of El Apante community. This selection was supported by the researcher's familiarity with the relevant theoretical background ("theoretical sensitivity") [53] (pp. 78-80) and is based on two criteria: geographical distribution (representation of all the community sectors) and level of the indigenous knowledge of the informant. The interviewing of the next informants, whose selection was based on the new meanings and categories that are emerging from the content of previous interviews [53], progressed until the saturation point [35], in which no new information related to the research question appeared. 
To identify this point, the content of each new interview transcript was compared with the previous one. This process is called theoretical sampling [53] (pp. 134-147). The semi-structured interviews were conducted in the frame of a personal visit to the selected households, which lasted between 3 and 6 hours. The interior and exterior of the house were also observed, including animals, plants, earth, and stones utilized by the interviewed household representatives in their daily life, and usually some traditional local refreshment was served. The research topics and related interview questions are listed in Table 1.

Table 1. The research topics and related interview questions.

\begin{tabular}{|c|c|}
\hline Research Topics & Research Questions \\
\hline Indigenous land ownership & $\begin{array}{l}\text { Is it possible to commercialize the indigenous land? } \\
\text { Is the private ownership of the indigenous land possible? } \\
\text { How is the indigenous land marked in terrain and how it is documented? }\end{array}$ \\
\hline $\begin{array}{l}\text { The traditional use of the stones } \\
\text { and earth }\end{array}$ & $\begin{array}{l}\text { How do you use different types of local stones? } \\
\text { How do you use different types of local earth/clay? } \\
\text { How long does the construction of your house last and which material do you use? }\end{array}$ \\
\hline The traditional land use & $\begin{array}{l}\text { Where and how large is your plot? } \\
\text { Which kind of crops do you cultivate there? } \\
\text { Do you rotate your crops? } \\
\text { Do you use any fertilizers? } \\
\text { Do you combine farming with forestry? } \\
\text { Which techniques do you use to manage pest control? } \\
\text { Which techniques do you use to prevent erosion? }\end{array}$ \\
\hline Land conservation & $\begin{array}{l}\text { What does the term "Mother Earth" mean to you? } \\
\text { Do you follow/respect some natural processes when using the natural resources? } \\
\text { Does the local indigenous authority cooperate with the state nature conservation? } \\
\text { Have you noticed some significant changes in the local environment, in the quality and/or } \\
\text { abundance of water, soil, forests, plants, animals etc.? }\end{array}$ \\
\hline Indigeneity & $\begin{array}{l}\text { What does it mean to you to be an indigenous person? } \\
\text { What is specific about the indigenous person, how (s)he differs from the persons } \\
\text { representing the dominant "colón" society (e.g., physiognomy, mentality, behaviour, } \\
\text { system of values, perception of nature and universe, time and space, death and birth)? } \\
\text { Which kind of practices and knowledge are principal for the indigenous identity? } \\
\text { What do you know about the origin of your indigenous community, about your ancestors? }\end{array}$ \\
\hline $\begin{array}{l}\text { Education and transmission } \\
\text { of knowledge }\end{array}$ & $\begin{array}{l}\text { Are the indigenous knowledge and practices transmitted to the younger generation? } \\
\text { Do you perceive the changes in the form of transmission? } \\
\text { Do you perceive any effects of these changes on the indigenous identity and on the relation } \\
\text { of local people to their land? }\end{array}$ \\
\hline $\begin{array}{l}\text { Position of Elders in } \\
\text { the community }\end{array}$ & $\begin{array}{l}\text { How do the Elders influence the decision-making processes of the community? } \\
\text { How do the Elders influence the decision-making processes of the family? }\end{array}$ \\
\hline $\begin{array}{l}\text { Nature related spirituality in the } \\
\text { daily practice, cosmology }\end{array}$ & $\begin{array}{l}\text { How do you relate to the plants, animals, stones, water and universe? } \\
\text { Do you observe the Moon's movement and other natural processes? } \\
\text { How do you use it for the timing indication in your daily life practice such as farming, } \\
\text { forestry, house construction, dating, etc.? }\end{array}$ \\
\hline Health, natural medicine & $\begin{array}{l}\text { Do you collect some medicinal plants? } \\
\text { Where do you collect them, is their abundance changing? } \\
\text { Which ones and how do you use them? } \\
\text { Do you perceive any changes in use of these plants; are the young people still interested in } \\
\text { their use? }\end{array}$ \\
\hline Customs, cuisine & $\begin{array}{l}\text { Do you use some plants for cooking? Which plants, which parts of them and how? } \\
\text { Do you collect them in the environs of your house or does your family cultivate them? }\end{array}$ \\
\hline Local sights and legends & $\begin{array}{l}\text { Which sites or natural phenomena of El Apante environs are of foremost importance for } \\
\text { the local indigenous community? Why? } \\
\text { Do you know some legend, myth or true story related to these sites or phenomena? }\end{array}$ \\
\hline Geopark & $\begin{array}{l}\text { Have you heard about the Rio Coco Geopark project? } \\
\text { What does it mean to you ("Earth park"), what do you expect from this initiative? }\end{array}$ \\
\hline Geotourism & $\begin{array}{l}\text { What do you think about possibility of sharing your house for some days with some } \\
\text { traveller? Would it be interesting for you? } \\
\text { Would it be possible to share your knowledge and your time with him/her, and to let } \\
\text { them eat and work with your family? }\end{array}$ \\
\hline
\end{tabular}




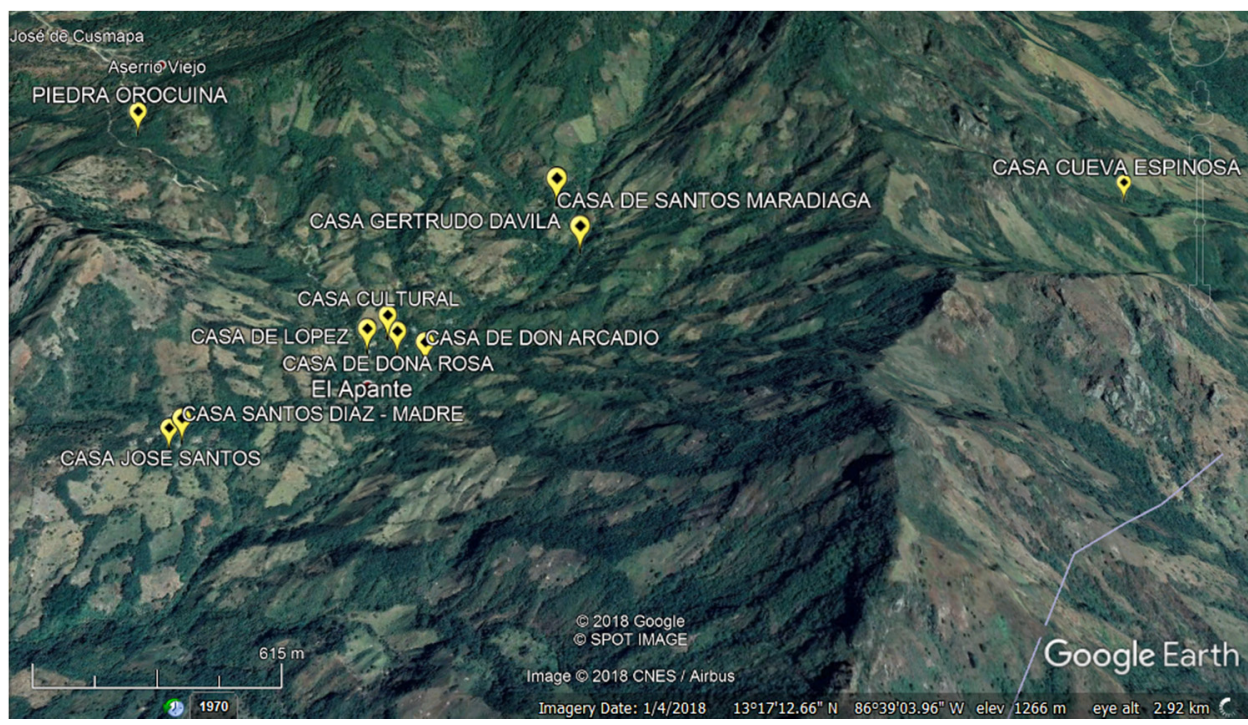

Figure 3. Research localities indicated by yellow icon (and described in capital letters) in the relief map of El Apante community. Source: Google Earth and GPS mapping.

Older informants were asked to relate their brief life histories [53] (p. 97). The location of each visited household was recorded with the help of a hand-held navigation GPS device and the house, including its living environment, was photo-documented. All of the narrations and the related author's entries were recorded using a digital audio recorder, as well as a field diary. The focal group discussion, which was held in the indigenous house ("casa cultural" or "Casa Indígena"), served as a platform for participatory validation $[33,36]$ of all the data collected in this research. The group consisted mainly of members of the Junta Indígena as persons with the supposed highest level of indigenous knowledge and responsibility. As a comprehensive conclusion of this discussion, a problem tree analysis was designed to identify collectively the key problems (indicated in the stem), the principal causes (described in the roots), and impacts of the problems (listed in the branches) [55]. This method is used typically for causal analysis of environmental or sanitary problems (e.g., [56]), but also recently for the environmental implication of indigenous knowledge [1] or for understanding Earth heritage from a geo-conservation perspective [57].

All of the communication with the local indigenous peoples was conducted in Spanish, which is the official language of Nicaragua. However, as mentioned above, they use their vernacular language, so that they call a majority of local plants and lot of local animals with names of Nahuatl origin, and the same applies for local toponyms. This did not create any substantial difficulties in communication with hosts and informants due to the author's familiarity with the region. Audio recording, photo-documentation, and publication of informants' narrations were carried out with their personal consent as well as with the permission of the Somoto Town Hall. This study was conducted in accordance with the Declaration of Helsinki, and the protocol was approved by the Ethics Committee of University of Hradec Králové, Czech Republic (No. 2110). With the mayor of the Somoto Town Hall, as a leader of the Rio Coco Geopark project, an unstructured interview was conducted concerning the opportunities and barriers of the usage of the local indigenous environmental knowledge in the management of geotourism and other geopark activities.

According to the grounded theory method [53,54], the data that were recorded during field research were transcribed and their content first analysed and then synthesized in repeated cycles until the point of theoretical saturation and theoretical model creation. The first part of the analysis, which served for basic grasp of the local indigenous knowledge, was done through the "open coding" [53] (pp. 220-236) of transcripts. This technique consisted in the identification the key meaning units and inducing more general categories relevant to the research question [53] (pp. 295-308). In the following phase of analysis, called the "axial coding" [54], these meaning units and categories (codes) 
were mutually related to reveal the indigenous knowledge potential for sustainability management of the geopark and its geotourism. To understand the causality of this potential, the necessary ("causal") conditions for its implementation, as well as the relevant external factors ("intervening conditions"), were identified. The process of the axial coding was strongly supported by the results of the problem tree causal analysis. The so-called "selective coding" involved creating the theoretical model where the most integrative ("core") category [53] (pp. 188-189) was related with all other categories. The core category represents an essential storyline of indigenous knowledge potential around which all of the generated codes (indigenous knowledge and related potential) and conditions for potential implementation are structured [53] (pp. 188-189). During the whole coding process, both analytical and theoretical notes ("memos") [53] (pp. 107-130) were recorded and were then used for the creation and description of the final model of indigenous knowledge potential.

\section{Results}

\subsection{Indigenous Konwledge and Meanings}

The observed, recorded and photo-documented indigenous knowledge as well as research method and localities are summed up in the Table 2.

The best maintained is knowledge concerning the wild growing plants and their use for healing and cooking. The Elders and women provided deeper information in this field; they still use this knowledge daily. The informants also described and demonstrated the traditional use of various volcanic stones (mainly andesite, dacite, or tuff), as well as of the local earth. Less information was provided on the traditional use of the local wild animals (for production of food and leather or for healing), probably because their hunting is prohibited in the nature reserve. The indigenous spirituality represented the least described field of shared knowledge, because it was victimized as illegal activity for long time. 
Table 2. Indicated knowledge and meanings, methods applied and research localities.

Research Locality

Household of Don Arcadio (77 years) and Doña Juana (76 years)

Sector I

(Sector Central)

$840 \mathrm{~m}$ a.s.l.
Applied Methods

Examples of the Observed Indigenous Knowledge

local volcanic stones used for marking of borders ("mojones" in the past: elaboration of obsidians and flints (in the house environs, archaeologists accompanied by the author discovered ancient pieces of ceramics and elaborated lithic material (mainly obsidian)

participant observation (living in the house of Don Arcadio for 2 weeks and sharing all the activities with its inhabitants)

recording notes in the field diary

life history of Don Arcadio

interviewing of the representatives of

the household

repeated visits of surroundings of the house

GPS mapping of the house location

photo-documentation of the house, its

inhabitants and surroundings local plants used for cooking: "basic grains" (corn, beans and or "chayote" (Sechium edule), called by indigenous "chaya" are used in the similar way as potatoes, the same applies for chayote fruits

plants used for medicine: e.g., "quebracho" (Aspidosperma), the bark of this tree is said to be anaesthetic, anti-fever and anting been tested through healing the author's injury with quebracho bark bath (boiled for $20 \mathrm{~min}$ )

plants used as repellent: e.g., "hoja blanca” (Buddleia americana) plants used as repellent: e.g., "hoja blanca" (Buddleia amer
to protect beans, "albahaca" (basil), onion, chili pepper local agro-ecology is strongly based on the lunar periodicity
Illustrative Photography

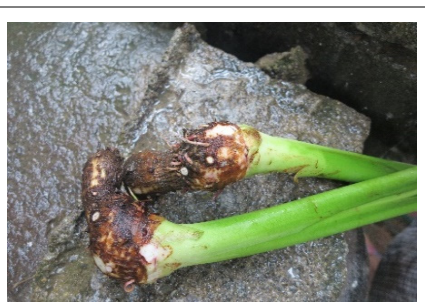

The "Malanga" washed on the stone

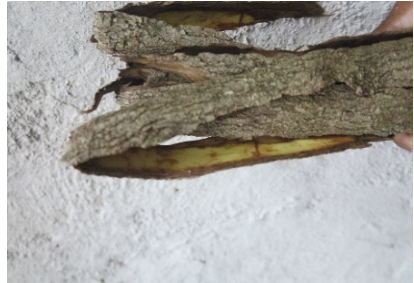

The fresh bark of the quebracho tree

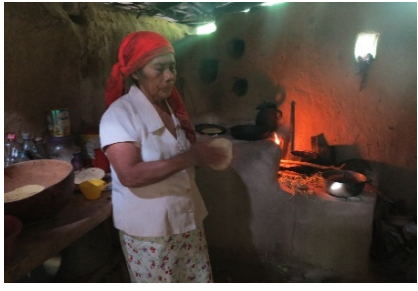

Tortillas production as a daily routine

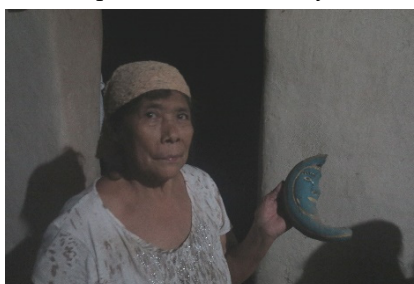

Lunar periodicity is at the core of indigenous cosmology 
Table 2. Cont

Research Locality

Applied Methods life history of Doña Rosa

interviewing of the representatives of

the household

participant observation (classifying corn) recording notes in the field diary

GPS mapping of the house location

photo-documentation of the house, its

inhabitants and surroundings
Examples of the Observed Indigenous Knowledge

Sector I

(Sector Central)

$857 \mathrm{~m}$ a.s.l.

\section{local volcanic stone (tuff) used for ages as millstone and pestle for grinding corn and coffee (she reuses the ancient millstones discovered in the slopes of the nearby San Cristobal hill) local plants used for medicine: e.g., "alcoton" is used as a plaster on wounds and it can also treat hypertension and bites of snakes use of local plants, e.g., "quapinol" called also "pacon " (Hymenaea courbaril) - the sap made from its fruits called "paconales" is used (mainly in the past) as soap for washing}

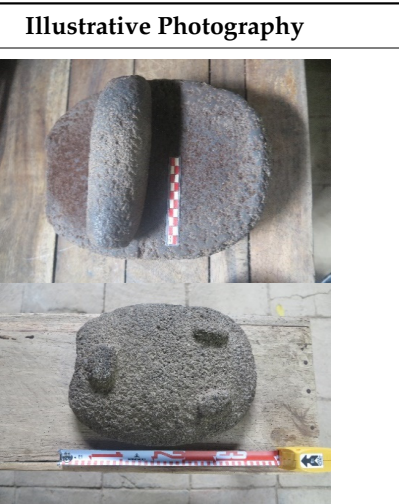

Ancient millstone found in El Apante Ancient millstone found in El Apante for crushing of coffee and corn

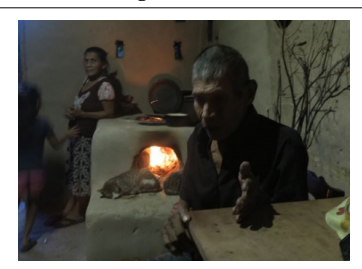

stone used e.g., as whetstone, manger, millstone, weight and construction material

earth used e.g., for production of roof tiles, bricks and ceramics the leather of cattle used for making of transport sacks ("argana") beds and chairs

interviewing of the representatives of

the household

Household of Don Anatolín (79 years)

(Sector Central)

recording notes in the field diary

GPS mapping of the house location

$870 \mathrm{~m}$ a.s.l. treats anaemia and rheumatism, "quina" (Chinchona) bark has anti-fever, antibiotic and antiseptic effects, liquidambar-bark of this

inhabitants and surroundings tree can relieve diarrhoea and oils made from its leaves have antiseptic effects, its resin is used not only to treat respiratory, gastrointestinal, gynaecological, urological, nerve and psychological problems, but also as incense

Don Anatolín (above) explains how to elaborate the "argana" bag (bellow)

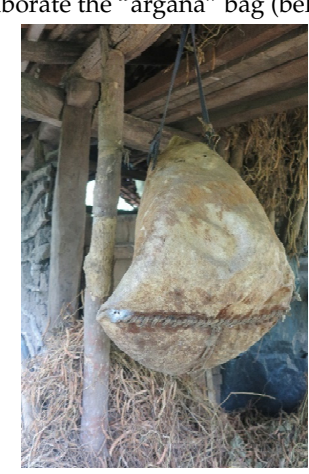


Table 2. Cont

Research Locality

Applied Methods

Household of Doña Santo

(70 years)

Sector II Ojo de agu

$899 \mathrm{~m}$ a.s.l. life history of Doña Santos

interviewing of the representatives of

the household

recording notes in the field diary

GPS mapping of the house location

photo-documentation of the house, its

inhabitants and surroundings
Examples of the Observed Indigenous Knowledge utensils, for construction of "barreras muertas" ("dead barriers" to prevent erosion), walls and base of the house (mainly dacite and andesite) "ladrillo")

local plants used for medicine: e.g., "dormilona” (Mimosis pudica) treats insomnia, diarrhoea and inflammation, and is used against parasites local volcanic stone used as washboard (tuff), for production of

earth used: e.g., making of stove, roof tiles and bricks ("adobe" and

Illustrative Photography
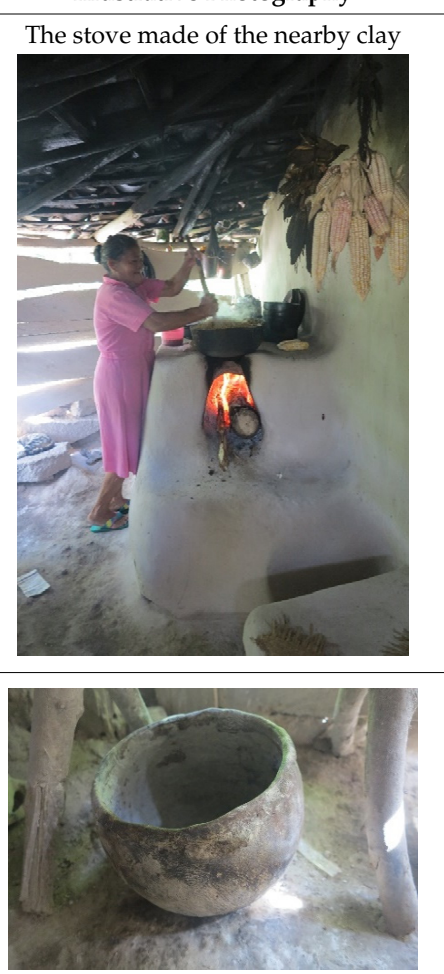

Natural bowls for beans, other "basic grains" and corn pancakes

its flexible and resis utensils: e.g., the "ficaro "tree (C and vases

local plants used for medicine: e.g., "juanilama” (Lippia alba) is used to relieve stomach and digestive problems and to treat colds, "picacuana" (Polygala paniculata) treats snake bites, and has antimicrobial and antidepressant effects

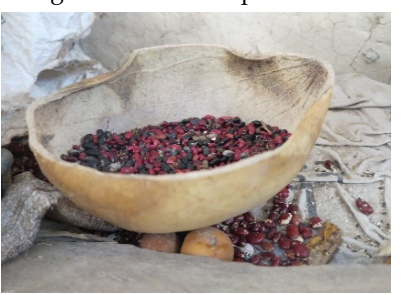


Table 2. Cont

interview with Don José

visit of the sector: local rock formation

interviewing of the representatives of the

distant household

recording notes in the field diary

GPS mapping of the house location

photo-documentation of the house, its

inhabitants and surroundings
Research Locality

Applied Methods

Examples of the Observed Indigenous Knowledge

Sector III Mangas Verdes (Geosite

$1003 \mathrm{~m}$ a.s.l. stone still used as a millstone for grinding of coffee and corn, as a whetstone and for polishing the furniture

earth used e $\alpha$ for production of tiles and ceramics (the ancient small plastic of the jaguar head) palm leaves used for production of baskets, bags, "tule" plant (Schoenoplectus acutus) was used not only for production

the local volcanic stone was of multiple use in the past: e.g., for production of arms, fireplaces
Illustrative Photography

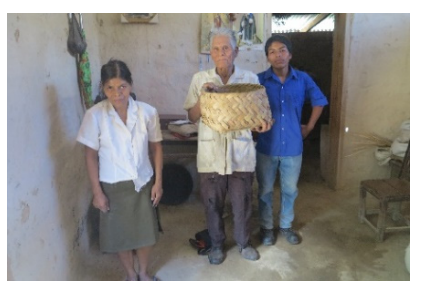

The palm leaves still serve for

production of bags, mats and baskets
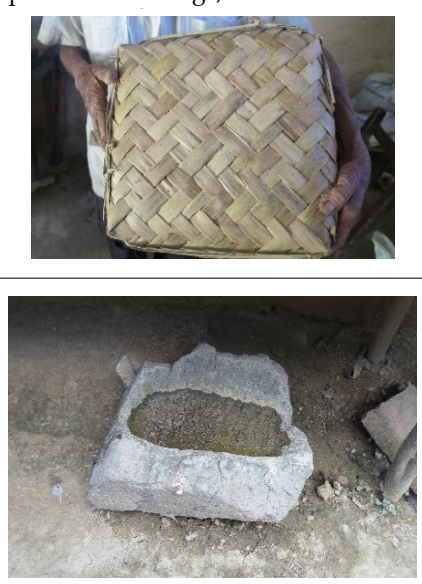

stone used: e.g., as manager for cattle, millstone, for construction houses and for borders marking ("mojones")

interview with Don Getrudo
interviewing of the representatives of interviewing of
the household

recording notes in the field diary

GPS mapping of the house location

(53 years)

photo-documentation of the house, its

$954 \mathrm{~m}$ a.s.l. earth used: e.g., for production of "adobe" bricks (clay with pine needles dried in the sun), "ladrillo" bricks (clay with cow dung burnt in the oven) and ceramics

local plants used for medicine: e.g. "jiñocuabo" or "indio desnudo" (Bursera simaruba)—-the leaves of this tree have anti-inflammatory effects, these trees serve also as "barrera viva" (living fence)
Eroded volcanic stone used as a manager for domestic animals and "ladrillos" prepared for burning

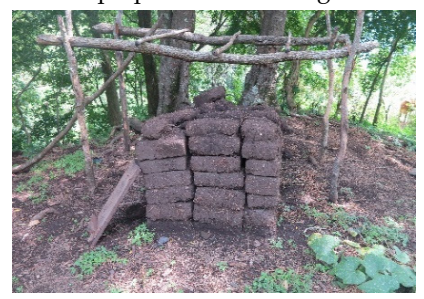


Table 2. Cont

Research Locality

Applied Methods

Examples of the Observed Indigenous Knowledge

life history of Don José

interviewing of the representatives of the household

Household of José (46 years) Cave near to El Arenal hill $798 \mathrm{~m}$ a.s.l.

GPS mapping of the house location

photo-documentation of the cave, it inhabitants and surroundings
The cave hidden at the foot of the El Arenal hill located near to the departmental border (between Madriz and Estelí) used as a house by the local family. Don José continues living there with his wife and three children as did his father. He expressed his happiness with their simple, but peaceful, undisturbed natural living environment, having the solid "roof" above his head, fresh water stemming from local spring and food provided directly by the "Mother Earth". He cultivates beans and corn.
Indigenous house ("casa cultural" or "Casa Indígena")$$
\text { Sector I }
$$$$
870 \mathrm{~m} \text { a.s.l. }
$$

discussion in focal group with "Problem Tree" identification

recording notes in the field diary

GPS mapping of the "Casa Indigena" location

photo-documentation of the "Casa Indígena" discussion participants and surroundings stone used: e.g., for construction of houses, for borders marking ("mojones"), whetstone and for polishing of furniture and weighting earth used: e.g., for construction of stoves, production of bricks ("adobe" and "ladrillo"), roof tiles and ceramics

the leather of cattle used for making of furniture (beds and chairs) and sacks for transport of provisions

use of animal fat: medicinal oils produced from the fat of hen, snake, pig or armadillo
Illustrative Photography

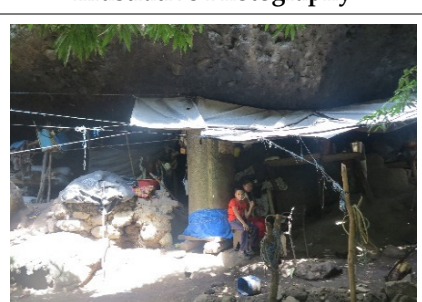

Cave used for living by local family
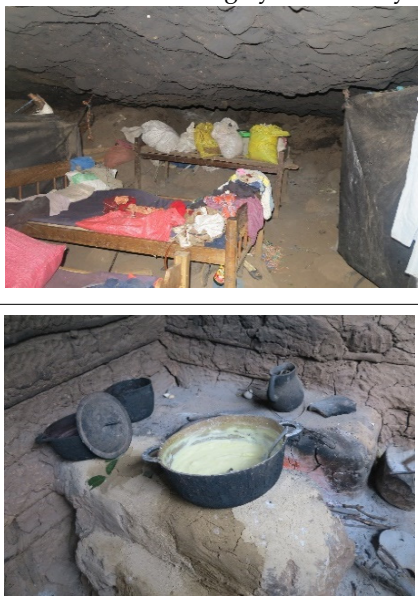

Corn as a base of local diet (e.g., "atol" pudding) represents a fertility symbo

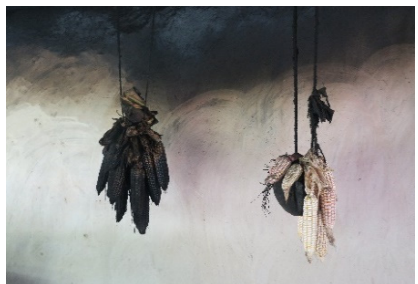


Table 2. Cont

Research Locality

Applied Methods

Examples of the Observed Indigenous Knowledge

$\begin{array}{ll}\text { visit of surroundings of the community of El } & \text { In the environs of this Tertiary volcanic formation, local archaeologists } \\ \text { Apante with two departmental archaeologists } & \text { accompanied by the author discovered ancient pieces of ceramics and }\end{array}$

two departmental archaeologists chiselled lithic material (mainly obsidian and flint) which indicates an

Piedra Orocuina rock

Coco Geopark,

recording notes in the field diary

indigenous ancestral settlement with possible ritual practices. Local

near to the road to San José de

GPS mapping of the house location

inhabitants narrate legends related to the Piedra Orucuina, e.g., about

photo-documentation of the hill and its

209 m as.1.

three small houses (in reality large stones), they also relate about
Honduras and they related that all rivers spring there.
Illustrative Photography

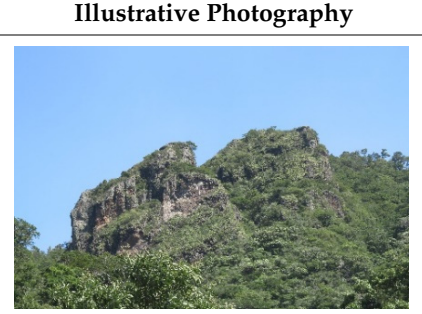

Piedra Orocuina, connected with

indigenous legends, is hiding ancient ceramic and lithic relicts at its foot. These sites are archaeologically under-researched.

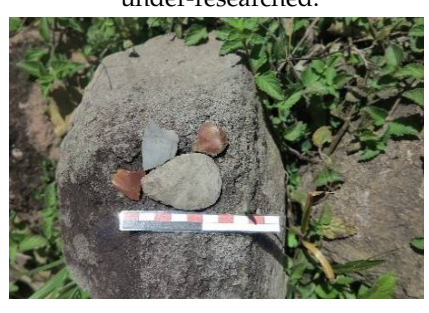




\subsection{Problems Related to Local Sustainability Management Identified by Local Indigenous People}

The tree of problems (Figure 4) concluded from the focal group discussion has facilitated the search for causal conditions and factors ("intervening conditions") of the indigenous knowledge potential of El Apante community for the sustainability management of the aspiring Rio Coco Geopark and its geotourism. It shows that the main problems are connected with the insufficient knowledge and transmission of the indigenous traditional knowledge regarding nature and its processes. The local people admit that, in the past, the land was more fertile and the pests were not so destructive. They feel that the preference for the comfort that was facilitated by the many artificial, but instant, food, medicine, instruments, construction materials, etc. is not only disconnecting them from their "Mother Earth", but also contaminating all of the resources provided by "her" for their subsistence. This kind of physical (land, natural resources) and mental (culture, spirituality) contamination that they perceived as a real danger connected to modern world. They expressed resolve to rediscover their ancestral and in some cases nearly forgotten practices regarding the Earth and universe, above all those regarding the use of the soil, vegetation, animals, water, and stone. They are convinced that this is necessary for their future subsistence, as well as for the maintenance of their indigenous identity.

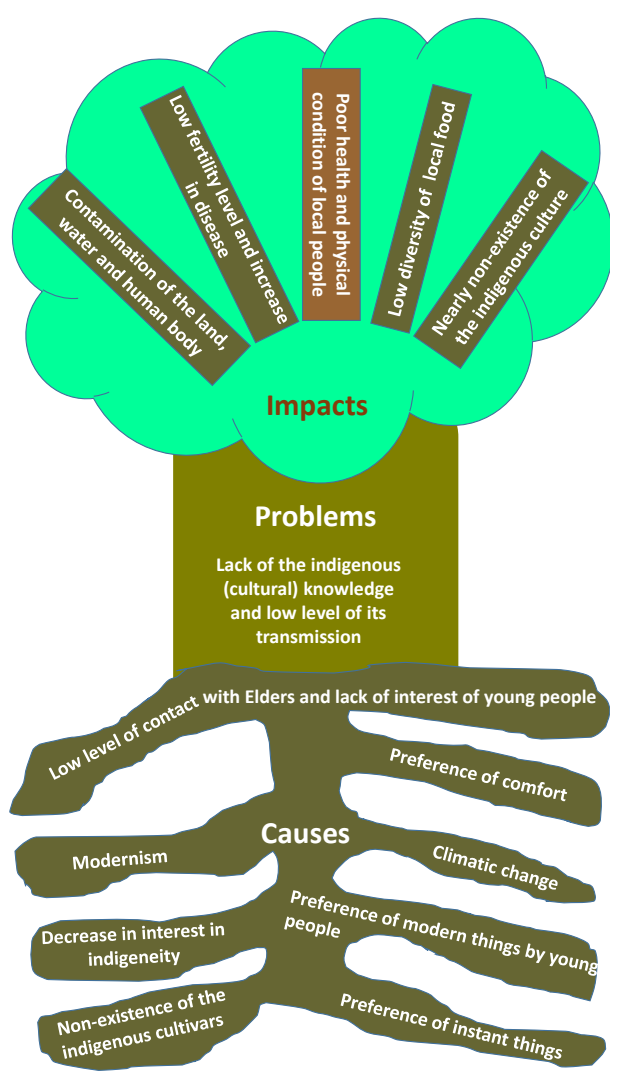

(a)

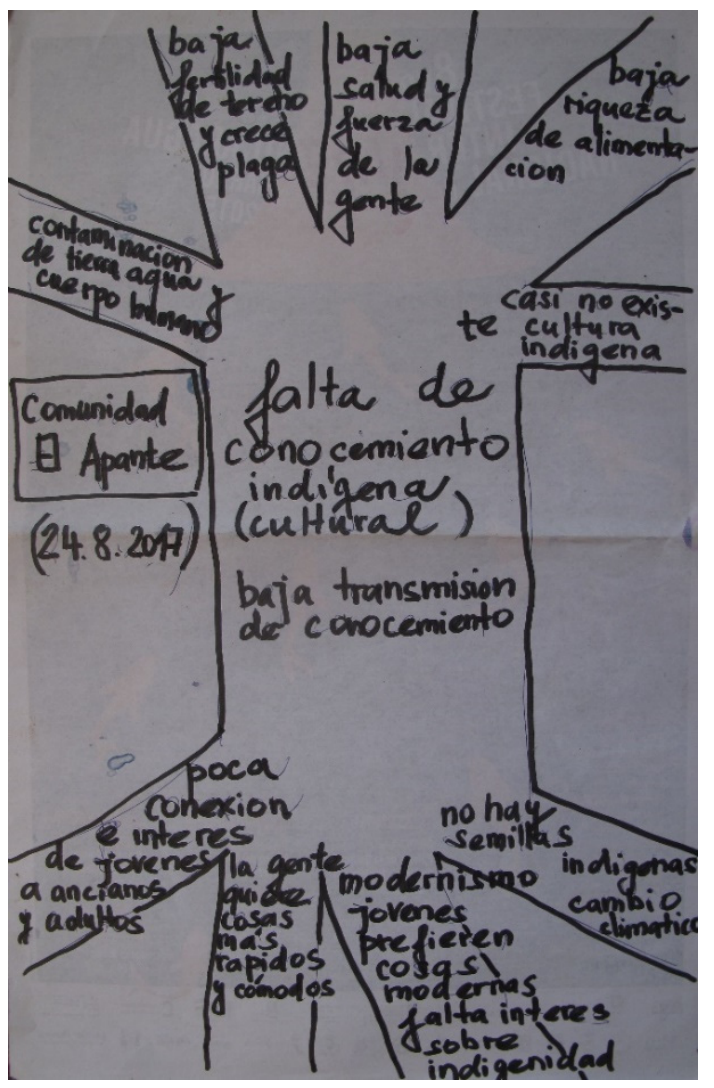

(b)

Figure 4. "Tree of problems" designed as a conclusion of the focal group discussion. (a) Schematic transcription in English; and, (b) Original picture.

\subsection{Indigenous Knowledge Potential for the Sustainability Management of the Geopark and Its Geotourism}

The results of the open and axial coding show the potential of the knowledge of the indigenous people living in the El Apante community to contribute to the sustainability management of aspiring Rio Coco Geopark, as well as to its geotourism sustainability management (Table 3). The causal conditions are the necessary requirements for the implementation of the identified potential, while the intervening conditions are external factors, which could constrain it. 
The key meaning units regarding the indigenous knowledge that is induced in the process of open coding are listed in column 1 of Table 3 . The categories concerning the indigenous knowledge potential identified in the frame of axial coding are described in the column 2 of Table 3. The conditions for the implementation of the knowledge potential, as well as the possible threats are listed in the column 3 of Table 3. Finally, the selective coding has led to the structuring of the whole "story" of the potential of the indigenous knowledge for the geopark sustainability management in the form of an abstract model (Figure 5).

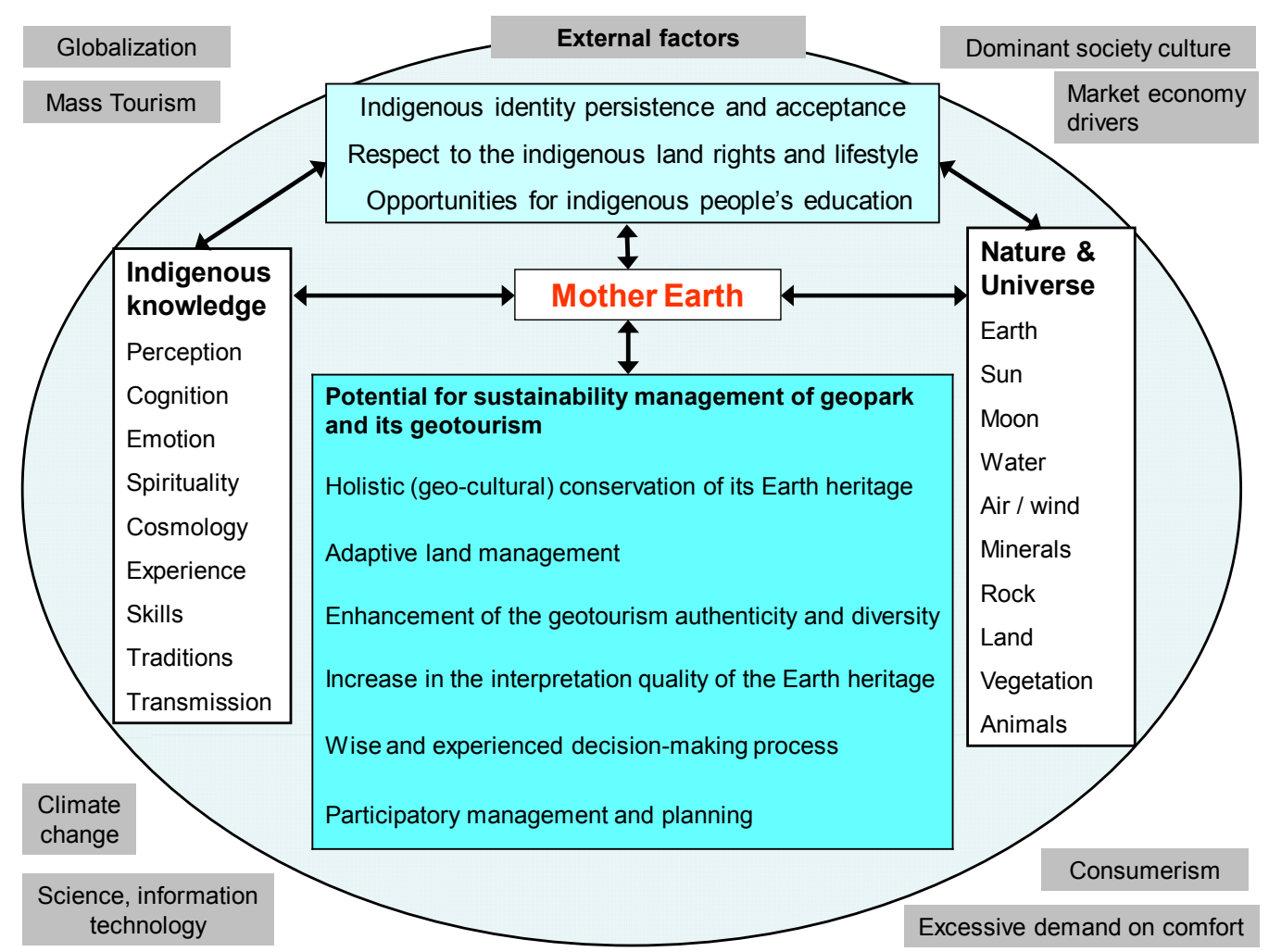

Figure 5. Model of indigenous knowledge potential for the geopark sustainability management.

The model of the indigenous knowledge potential for geopark sustainability management is composed of the core category "Mother Earth", meaning units of the indigenous knowledge, categories of the indigenous knowledge potential, as well as the causal and intervening conditions for the potential implementation [53,54]. The core category "Mother Earth" is of prime importance both for the indigenous knowledge and for the geopark (which can be translated as "Earth park"). The crucial causal condition for the indigenous knowledge potential of El Apante community for the sustainability management of the aspiring Rio Coco Geopark and its geotourism is the persistence and acceptance of the indigenous identity, as mentioned above. The external factors of globalization, market economy drivers, consumerism, dominant society culture, climate change, etc. are among the key intervening conditions. The context of the researched phenomenon concerning the potential of the indigenous knowledge for the sustainability management of the aspiring geopark and its geotourism comprises modalities of the indigenous knowledge (e.g., its perception, cognition, spirituality, tradition, and transmission), as well as the related nature and universe elements. 
Table 3. The potential of the indigenous knowledge of El Apante community to contribute to the sustainability management of aspiring Rio Coco Geopark, especially to its geotourism and related activities.

\begin{tabular}{|c|c|c|}
\hline The Indigenous Knowledge & $\begin{array}{l}\text { Potential for the Sustainability Management of the Aspiring } \\
\text { Geopark and Its Geotourism }\end{array}$ & $\begin{array}{l}\text { Causal Conditions of the Potential Implementation } \\
\text { and Intervening Conditions }\end{array}$ \\
\hline $\begin{array}{l}\text { Use of stone, earth, plants and other natural resources } \\
\text { for construction of houses, walls, and stoves, as } \\
\text { manager, washboard, millstone, pestle, for production } \\
\text { of furniture, dishes, baskets, sacks, bags, mats, etc. }\end{array}$ & $\begin{array}{l}\text { Prevention of the soil, water and air contamination of the geopark } \\
\text { territory through increased use of the natural recyclable materials, } \\
\text { increase in the geotourism diversity through participatory } \\
\text { interpretation of the use of the local volcanic stones and other } \\
\text { natural materials }\end{array}$ & $\begin{array}{l}\text { Systematic public education in geopark territory involving values } \\
\text { system change, which can relieve the factors as market economy } \\
\text { drivers, excessive demand for comfort and modernity, i needed. }\end{array}$ \\
\hline $\begin{array}{l}\text { "Family farming" mainly for auto-consumption, } \\
\text { without any fertilizers (or just with organic ones), } \\
\text { practice of agroforestry system (especially silvopastoral) } \\
\text { and rotation system, using the "dead barriers" and } \\
\text { "living fences", diverse composition of crops, the use of } \\
\text { the local both cultivated and wild plants for cooking }\end{array}$ & $\begin{array}{l}\text { Contamination prevention of the human body and local environment } \\
\text { (caused by chemical preservatives and fertilizers, transport } \\
\text { emissions, etc.) through an increased level of implementation of the } \\
\text { organic, small size farming, agroforestry system, increase in the } \\
\text { geotourism diversity through the participatory geo-gastronomic } \\
\text { programs with use of local crops, plants and herbs including the } \\
\text { interpretation of soil composition and characteristics }\end{array}$ & $\begin{array}{l}\text { The rights of indigenous communities on their indigenous lands } \\
\text { must no longer be violated. } \\
\text { The organic, diversified "family farming" must be preferred to the } \\
\text { large monocultural farming with chemical treatment. } \\
\text { The visitors' fear of the quality of the local hygiene should } \\
\text { be relieved. }\end{array}$ \\
\hline $\begin{array}{l}\text { Local indigenous identity based on the connection to } \\
\text { "Mother Earth" as basis of ife }\end{array}$ & $\begin{array}{l}\text { More holistic approach to conservation and interpretation of Earth } \\
\text { heritage-an increased stress on the interconnection between the } \\
\text { natural and spiritual values of the Earth heritage, increased } \\
\text { geotourism authenticity through the participation of local } \\
\text { indigenous geoguides and georangers }\end{array}$ & $\begin{array}{l}\text { The conservative approach to nature conservation, strictly separating } \\
\text { the science and culture, should be avoided; the acceptance of } \\
\text { coexistence of the different, indigenous value system is needed. } \\
\text { Local indigenous people must have opportunities for education } \\
\text { concerning the local geology, ecology, archaeology and anthropology. }\end{array}$ \\
\hline $\begin{array}{l}\text { The position of Elders in the decision-making processes } \\
\text { and mentoring }\end{array}$ & $\begin{array}{l}\text { Involvement of voices of wisdom through engagement of Elders and } \\
\text { women into the decision-making processes of geopark management, } \\
\text { since they have proved to have higher level of } \\
\text { indigenous knowledge }\end{array}$ & $\begin{array}{l}\text { The consultation with "Consejos de Ancianos" (Councils of Elders) } \\
\text { must be incorporated into the decision-making processes of the } \\
\text { aspiring geopark management. }\end{array}$ \\
\hline $\begin{array}{l}\text { Spirituality and cosmology related to the land use and } \\
\text { use of other natural resources, use of lunar } \\
\text { methodologies enhancing the respect for cyclic } \\
\text { natural processes }\end{array}$ & $\begin{array}{l}\text { Implementation of the carrying capacity concept in Earth heritage } \\
\text { conservation through observing the rhythm of local natural } \\
\text { processes (leaving some time and space for recuperation of } \\
\text { ecosystems and their various elements) }\end{array}$ & $\begin{array}{l}\text { The public mistrust of spiritually based knowledge and conservative } \\
\text { approach to nature conservation, strictly separating the science and } \\
\text { culture, must be avoided. }\end{array}$ \\
\hline $\begin{array}{l}\text { Transmission of indigenous knowledge, practices } \\
\text { and legends }\end{array}$ & $\begin{array}{l}\text { An increase in the geotourism diversity and authenticity-a } \\
\text { challenge for local geoguiding system with use of local indigenous } \\
\text { knowledge including legends, myths and stories }\end{array}$ & $\begin{array}{l}\text { The traditional intergenerational oral face-to-face communication } \\
\text { must be supported. The system of education for local geoguides and } \\
\text { Earth heritage interpretation must be prepared. }\end{array}$ \\
\hline $\begin{array}{l}\text { The use of medicinal plants and indigenous } \\
\text { healing techniques }\end{array}$ & $\begin{array}{l}\text { An improvement of the health and related knowledge of the geopark } \\
\text { population, increase in the geotourism diversity through } \\
\text { participatory geo-medical and geo-meditative programs with use of } \\
\text { knowledge of the local plants and related specific soil characteristics }\end{array}$ & $\begin{array}{l}\text { The conservative approach and prejudices to the "natural medicine" } \\
\text { should be avoided. Local indigenous people must have } \\
\text { opportunities for education concerning the local botany, ecology } \\
\text { and anthropology. }\end{array}$ \\
\hline
\end{tabular}




\section{Discussion and Conclusions}

\subsection{Sustainability, Maintanance, Transmission and Documentation of the Indigenous Knowledge}

The case study conducted in El Apante community indicates that the majority of identified practices of the traditional land use and the use of the other natural resources that were identified in the southern part of the aspiring Rio Coco Geopark seems to be more sustainable than many modern practices used in agriculture, medicine, building and decoration of constructions, etc. The leaders of the indigenous community El Apante are strongly aware of the fact that they should dedicate much more attention and efforts to rediscover, transmit and enhance use their traditional environmental knowledge and thus to improve not only the sustainability of their life and geotourism emerging in the aspiring Rio Coco Geopark, but also to reactivate their indigenous identity.

The indigenous inhabitants of El Apante community have been maintaining more of their ancestral environmental knowledge in comparison with the indigenous inhabitants that are living in the urban cores of the indigenous municipalities (San José de Cusmapa, Totogalpa, and San Lucas) [8-11]. They do not document any elements and aspects of their ancestral indigenous knowledge, but they apply them in their daily practices and decision-making. The young generation is not much interested in this kind of knowledge because they build and accumulate their knowledge predominantly in the school and not any more mainly through observing, helping, and listening to Elders. In the local schools, the curricula do not include indigenous identity and knowledge building.

The documentation of the indigenous knowledge is necessary for its conservation; however, it is contradictory and thus problematic. The contradiction stems from the fact that the indigenous knowledge transmission is realized exclusively in the oral way. This kind of transmission is a fundamental feature of the indigenous knowledge, value system, and lifestyle. This situation was reflected during both present and previous [8-11] field research, when it was evident that indigenous peoples are not in the habit of documenting or arranging the meetings regarding the indigenous knowledge. Many of the Elders were illiterate, but extremely wise, preferring the oral communication for intergenerational transmission to the written or even digital documentation. The researcher should adapt to this situation and accept the long-term character of this kind of research, which needs years of communication and sharing of indigenous living.

\subsection{Implementation of the Potential of the Indigenous Knowledge for the Aspiring Geopark Sustainability}

Implementation of the key indigenous knowledge potential identified in this study presents challenges for the adaptive land management of the aspiring geopark, holistic (geo-cultural) approach to its Earth heritage conservation, enhancement of the geotourism authenticity and diversity and improvements in the interpretation quality of the local geoheritage. The wise and experienced decision-making process and participatory management represent another important potential of indigenous knowledge for the aspiring geopark management. However, the implementation of all described potential is conditioned; among the central conditions are the persistence and acceptance of the indigenous identity of the indigenous communities in the aspiring geopark, general respect to their rights to land resources and lifestyle based on different value system as well as the creation of opportunities for indigenous people's education in various disciplines of Earth science.

\subsection{Recommendation for the Aspiring Geopark Management and Future Research}

The indigenous knowledge has the potential to make the aspiring geopark both environmentally and socially sounder and its geotourism more diverse and authentic. However, its implementation depends on the meeting of specific requirements, as well as on the avoiding the identified threats. Recognition of the indigenous identity, as the causal condition, must be among the highest priorities of the geopark management. The schooling must not only include the indigenous knowledge in its curricula, but it must be adapted to the indigenous value system and lifestyle. The lessons for indigenous pupils should not be held predominantly in the classes but in their living environment, 
which would enable the development of their inherited indigenous genetics as well as the transmitted indigenous knowledge. The same applies for the educational activities for the indigenous peoples in the Earth science disciplines, they must be arranged prevailingly as outdoor activities in El Apante community, not in classes in San José de Cusmapa or even in Somoto. The decision making process of the aspiring geopark must involve the "Junta Indígena" and mainly the "Consejo de Ancianos" (Council of Elders) of El Apante community as well as the other geopark indigenous communities. These indigenous authorities should be in charge of the geopark mission dissemination and implementation in their areas. Education of the general public concerning the indigenous value system, cosmology, natural medicine, and lifestyle is necessary for gradual increase in acceptance of the indigenous culture as equal. Geotourism in the indigenous communities as El Apante must be never massive; the number of visitors should not overpass the one-half of the indigenous population size in order to avoid tourism negative impacts (e.g., [58,59]). This geotourism should be realized, according to the informants, in the form of cohabitation, sharing the house, food, environment, and knowledge.

In this context, the research achievements are twofold. First, the potential contribution of indigenous knowledge of the inhabitants of the El Apante community to the sustainability management of the aspiring Rio Coco Geopark was identified. Second, the research process itself has not only attracted attention from the local indigenous peoples in the aspiring geopark initiative and its emerging geotourism, but it also has invigorated the dignity, confidence, and self-respect concerning their ancestral knowledge and traditional lifestyle.

The applicability and credibility of holistic and cross-disciplinary research approaches as well as the local based and participatory research strategies are of crucial importance for "sustainability science", as an emerging academic discipline [8]. A systematic epistemological synthesis that is based on the wisely balanced combination of the local and indigenous knowledge provided typically by idiographic research and modern scientific knowledge stemming from nomothetic research [8] is extremely important for adaptive management research and practice.

Future research on the environmental potential of indigenous knowledge should stress the perception of this potential by the young generation of indigenous peoples, as well as the conditions for acceptance of the more holistic and culturally sensitive environmental management approach. These aspects proved to be weak points for future applications of the perceived, studied, and already identified environmental capacity of the ancestral indigenous wisdom. Maintenance and responsible use of traditional knowledge are important, not only for the effective involvement of the indigenous communities in the geopark management, but also for improvement of its geotourism diversity and sustainability.

Funding: This research was financially supported by the Faculty of Informatics and Management of the University of Hradec Králové (FIM UHK) in the frame of the Specific Research Project "Information and knowledge management and cognitive science in tourism".

Acknowledgments: The author wishes to express her thanks to Dominik Rejchrt, FIM UHK student, who assisted with the graphical elements of this contribution. Author also would like to acknowledge the facilitation of the research process provided by staff of the Authority of Somoto Municipality.

Conflicts of Interest: The author declares no conflict of interest. The Municipality of Somoto, which facilitated the research process by providing assistance staff and logistic support, had no role in the design of the study; in the collection, analyses, or interpretation of data; in the writing of the manuscript, and in the decision to publish the results.

\section{References}

1. Pásková, M.; Zelenka, J. Social responsibility role in tourism sustainability. In Proceedings of the Hradec Economic Days; Jedlička, P., Ed.; Gaudeamus: Hradec Králové, Czech Republic, 2016.

2. Starik, M.; Kanashiro, P. Toward a theory of sustainability management: Uncovering and integrating the nearly obvious. Organ. Environ. 2013, 26, 7-30. [CrossRef]

3. Hörisch, J.; Freeman, R.E.; Schaltegger, S. Applying stakeholder theory in sustainability management. Links, similarities, dissimilarities, and a conceptual framework. Organ. Environ. 2014, 27, 328-346. [CrossRef] 
4. Butler, C.F.; Menzies, C.R. Traditional ecological knowledge and indigenous tourism. In Tourism and Indigenous Peoples; Butler, R., Hinch, T., Eds.; Butterworth-Heinemann: Oxford, UK, 2007.

5. Thompson, A.; Ruhanen, L.; Whitford, M. Indigenous peoples and tourism: the challenges and opportunities for sustainable tourism. J. Sustain. Tour. 2016, 24, 1-13.

6. Espeso-Molinero, P. Collaborative capacity building as a resilience strategy for tourism development in indigenous Mexico. In Tourism, Resilience, and Sustainability: Adapting to Social, Political and Economic Change; Cheer, J., Lew, A.A., Eds.; Routledge: Tranmere, UK, 2018.

7. Farsani, N.T.; Coelho, C.; Costa, C. Geotourism and geoparks as gateways to socio-cultural sustainability in Qeshm Rural Areas, Iran. Asia Pac. J. Tour. Res. 2012, 17, 30-48. [CrossRef]

8. Pásková, M. Local and indigenous knowledge regarding the land use and use of other natural resources in the aspiring Rio Coco geopark. In IOP Conference Series: Earth and Environmental Science; IOP Publishing Ltd.: Prague, The Czech Republic, 2017. [CrossRef]

9. Pásková, M. The potential of indigenous knowledge for Rio Coco Geopark Geotourism. Procedia Earth Planet. Sci. 2015, 15, 886-891. [CrossRef]

10. Pásková, M.; Hradecký, P. Aspiring Geopark Rio Coco (Nicaragua). In Proceedings of the SGEM Conference Proceedings, Albena, Bulgaria, 17-26 June 2014.

11. Pásková, M.; Dowling, R.K. The usage of local and indigenous knowledge in the management of geotourism destinations. In Proceedings of the SGEM Conference Proceedings, Albena, Bulgaria, 17-26 June 2014.

12. Dowling, R.K. Global geotourism-An emerging form of sustainable tourism. Czech J. Tour. 2013, 2, 59-79. [CrossRef]

13. Nakashima, D.; Roué, M. Indigenous knowledge, peoples and sustainable practice. In Encyclopedia of Global Environmental Change; Timmerman, P., Ed.; John Wiley \& Sons, Ltd.: Chichester, UK, 2002.

14. Guchteneire, P.; Krukkert, I.; Liebenstein, G. Best Practices on Indigenous Knowledge; Bowen, K., Morohashi, J., Eds.; Nuffic: Tha Hague, The Netherlands; UNESCO: Paris, France, 1999.

15. Roué, M.; Nakashima, D. Knowledge and foresight: The predictive capacity of traditional knowledge applied to environmental assessment. Intern. Soc. Sci. J. 2002, 54, 337-347. [CrossRef]

16. UNESCO. Learning and Knowing in Indigenous Societies Today; Bates, P., Chiba, M., Kube, S., Nakashima, D., Eds.; UNESCO: Paris, France, 2009.

17. Toledo, V. Indigenous peoples and biodiversity. In Encyclopedia of Biodiversity; Levin, S.A., Ed.; Academic Press: Cambridge, MA, USA, 2000.

18. Gray, A.; Parellada, A.; Newing, H. Indigenous peoples and biodiversity conservation in Latin America: From principles to practice. In Proceedings of the Pucallpa Conference; IWGIA Document No. 87; IWGIA: Copenhagen, Denmark, 1998.

19. Mallarach, J.M. Protected Landscapes and Cultural and Spiritual Values. Values of Protected Landscapes and Seascapes Series No. 2; Kasparek Verlag on behalf of IUCN, GTZ and Social de Caixa Obra Catalunya: Heidelberg, Germany, 2009.

20. Nemeth, K.; Cronin, S.J. Volcanic structures and oral traditions of volcanism of Western Samoa (SW Pacific) and their implications for hazard education. J. Volcanol. Geotherm. Res. 2009, 186, 223-237. [CrossRef]

21. Cashman, K.V.; Cronin, S.J. Welcoming a monster to the world: Myths, oral tradition, and modern societal response to volcanic disasters. J. Volcanol. Geotherm. Res. 2008, 176, 407-418. [CrossRef]

22. Henige, D. Can a myth be astronomically dated? (Iroquois League, oral tradition, solar eclipse). Am. Indian Cult. Res. J. 1999, 23, 127-157. [CrossRef]

23. Lauer, M. Oral traditions or situated practices? Understanding how indigenous communities respond to environmental disasters. Hum. Organ. 2012, 71, 176-187. [CrossRef]

24. Palacio-Prieto, J.L.; Rosado-González, E.; Ramírez-Miguel, X.; Oropeza-Orozco, O.; Cram-Heydrich, S.; Ortiz-Pérez, M.A.; Figueroa-Mah-Eng, J.M.; de Castro-Martínez, G.F. Erosion, culture and geoheritage; the case of Santo Domingo Yanhuitlan, Oaxaca, Mexico. Geoheritage 2016, 8, 359-369. [CrossRef]

25. Moodie, D.W.; Catchpole, A.J.W.; Abel, K. Northern Athapaskan Oral traditions and the White River Volcano. Ethnohistory 1992, 39, 148-171. [CrossRef]

26. Fepuleai, A.; Weber, E.; Németh, K.; Muliaina, T.; Iese, V. Eruption styles of Samoan volcanoes represented in tattooing, language and cultural activities of the indigenous people. Geoheritage 2017, 9, 395-411. [CrossRef]

27. Gros, P.M.; Frithz, N.M. Conocimientos del Pueblo Mayangna Sobre la Convivencia del Hombre y la Naturaleza. Peces y Tortugas Tomo 1; UNESCO Office: Paris, France, 2010. 
28. Gros, P.M.; Frithz, N.M. Conocimientos del Pueblo Mayangna Sobre la Convivencia del Hombre y la Naturaleza. Peces y Tortugas Tomo 2; UNESCO Office: Paris, France, 2010.

29. Colding, J.; Folke, C.; Elmqvist, T. Social institutions in ecosystem management and biodiversity conservation. Trop. Ecol. 2003, 44, 25-41.

30. Samakov, A. Sacred Sites: Opportunity for Improving Biocultural Conservation and Governance in Ysyk-Köl Biosphere Reserve, Kyrgyz Republic. Master's Thesis, University of Manitoba, Winnipeg, MB, Canada, 2015.

31. Klubnikin, K.; Annett, C.; Cherkasova, M.; Shishin, M.; Fotieva, I. The sacred and the scientific: Traditional ecological knowledge in Siberian river conservation. Ecol. Appl. 2000, 10, 1296-1306. [CrossRef]

32. Berkes, F.; Colding, J.; Folke, C. Rediscovery of traditional ecological knowledge as adaptive management. Ecol. Appl. 2000, 10, 1251-1262. [CrossRef]

33. Cid, V. Manual de Investigación Cultural Comunitaria: Herramientas Cultura y Desarrollo 1; UNESCO Office: San José, Costa Rica, 2012.

34. Kassam, K.-A.S.; Graham, J.R. Indigenous knowledge, community participation, and traditional land use mapping. In Social Work \& Aboriginal Peoples: Perspectives from Canada's Rural and Provincial Norths; Brownlee, K., Neckoway, R., Delaney, R., Durst, D., Eds.; Lakehead University, Center for Northern Studies: Thunder Bay, ON, Canada, 2010.

35. Gratani, M.; Bohensky, E.L.; Butler, J.R.A.; Sutton, S.G.; Foale, S. Experts' Perspectives on the Integration of Indigenous Knowledge and Science in Wet Tropics Natural Resource Management. Aust. Geogr. 2014, 45, 167-184. [CrossRef]

36. Cronin, S.J.; Gaylord, D.R.; Charley, D.; Alloway, B.V.; Wallez, S.; Esau, J.W. Participatory methods of incorporating scientific with traditional knowledge for volcanic hazard management on Ambae Island, Vanuatu. Bull. Volcanol. 2004, 66, 652-668. [CrossRef]

37. Brush, S.B. Indigenous knowledge of biological resources and intellectual property rights: The role of anthropology. Am. Anthropol. 1993, 95, 653-671. [CrossRef]

38. Wenzel, G.W. Traditional ecological knowledge and Inuit: Reflections on TEK research and ethics. Arctic 1999, 52, 113-124. [CrossRef]

39. Beltrán, J.; Phillips, A. Indigenous and Traditional Peoples and Protected Areas. Principles, Guidelines and Case Studies; IUCN: Gland, Switzerland and Cambridge, UK; WWF International: Gland, Switzerland, 2000.

40. Simonič, P. Etnography of Protected Areas. Engangered Habitats-Engangered Cultures; University of Ljubljana: Ljubljana, Slovenia, 2006.

41. Borrini-Feyerabend, G.; Kothari, A.; Oviedo, G. Indigenous and Local Communities and Protected Areas. Towards Equity and Enhanced Conservation Guidance on policy and practice for Co-managed Protected Areas and Community Conserved Areas; IUCN: Gland, Switzerland; Cambridge, UK, 2004.

42. Wiliamson, M.; Mendoza, M.J.; Valerio, L.; Garcia, R.; del Cid, V.; Mendoza, J.; Castro, W.; Salas, R. Pueblos Originarios y Afrodescendientes de Nicaragua Etnografía, Ecosistemas Naturales y Áreas Protegidas; IBIS-Education for development: Hong Kong, China, 2016.

43. UNESCO Global Geoparks. Available online: http://www.unesco.org/new/en/natural-sciences/ environment/earth-sciences/unesco-global-geoparks/top-10-focus-areas/ (accessed on 2 May 2018).

44. Dosier de Candidatura del Proyecto de Geoparque Río Coco; Archive of the Somoto Town Hall; Alcaldía de Somoto: Somoto, Nicaragua, 2017.

45. Barth, F. An anthropology of knowledge. Curr. Anthropol. 2002, 43, 1-18. [CrossRef]

46. Johnston, R.J.; Gregory, D.; Pratt, G.; Watts, M. The Dictionary of Human Geography, 4th ed.; Wiley-Blackwell: Hoboken, NJ, USA, 2000.

47. Semple, E.C.; Ratzel, F. Influences of Geographic Environment, on the Basis of Ratzel's System of Anthropo-Geography; H. Holt and Co.: New York, NY, USA, 1911.

48. Plan de Manejo Reserva Natural Serranía Tepesomoto y Pataste; Ministerio del Ambiente y los Recursos Naturales; MARENA: Managua, Nicaragua, 2008.

49. Navarro-Genie, R.; Eveha Nicaragua, Managua, Nicaragua. Personal communication, 2018.

50. Werner, P.S. Ethnohistory of the Early Nicaragua. Demography and Encomiendas of Communities; Occasional Publication No. 4; Institute for Mesoamerican Studies, The University at Albany: Albany, NY, USA, 2000. 
51. Fundación Nicaragüense para el Desarrollo Sostenible FUNDENIC—SOS. Evaluación y Redefinición del Sistema de Áreas Protegidas Serranía de Tepesomoto-Pataste de las Regiones Pacífico y Centro Norte de Nicaragua. MARENA-PROTIERRA-CBA. Informe Final, 1-30 2000. Available online: http:/ / www.bvsde. org.ni/Web_textos/MARENA/MARENA0217/EvalRedSistAreasProtSerraniaTepesomoto_\%20Pataste.pdf (accessed on 1 May 2018).

52. Diagnostico Socioeconomico Subcuenca Rio Tapacali, Madriz; Archive of the San Jose de Cusmapa Town Hal; Alianza por la Resiliencia: San José de Cusmapa, Nicaragua, 2014.

53. Corbin, J.; Strauss, A. Basics of Qualitative Research. Techniques and Procedures for Developing Grounded Theory, 4th ed.; SAGE Publications, Inc.: London, UK, 2015.

54. Strauss, J.; Corbin, A. Basics of Qualitative Research. Qual. Sociol. 1990, 13, 3-21.

55. Barreto-Dillon, L. Problem Tree Analysis, 2018 Sustainable Sanitation and Water Management Toolbox. Available online: https:/ / www.sswm.info/planning-and-programming/decision-making/situation-andproblem-analysis/problem-tree-analysis (accessed on 12 July 2018).

56. Conradin, K. Ecological Sanitation in the Khuvsgul Area, Northern Mongolia: Socio-Cultural Parameters and Acceptance. Master's Thesis, University of Basel, Basel, Switzerland, 2007.

57. Reynard, E.; Brilha, J. Geoheritage: Assessment, Protection, and Management; Elsevier: Amsterdam, The Netherlands, 2018.

58. Ryan, C.; Aicken, M. Indigenous Tourism. The Commodification and Management of Culture; Routledge: Tranmere, UK, 2005.

59. Pásková, M. Negative impacts of tourism and sustainable tourism as an alternative for regional development. In Proceedings of the 3rd Moravian Geographical Conference CONGEO'99, Regional Prosperity and Sustainability, Slavkov u Brna, Czech Republic, 6-10 September 1999.

(C) 2018 by the author. Licensee MDPI, Basel, Switzerland. This article is an open access article distributed under the terms and conditions of the Creative Commons Attribution (CC BY) license (http:/ / creativecommons.org/licenses/by/4.0/). 